\title{
Pengaruh Nilai Tukar terhadap Return Saham dengan Profitabilitas sebagai Variabel Intervening
}

\author{
Made Dewi Gita Puspita Lestari ${ }^{1}$ \\ Fakultas Ekonomi dan Bisnis \\ Universitas Udayana, Indonesia \\ Email: gitapuspita0110@gmail.com
}

\author{
I Gusti Ngurah Agung Suaryana ${ }^{2}$ \\ Fakultas Ekonomi dan Bisnis \\ Universitas Udayana, Indonesia
}

\begin{abstract}
ABSTRAK
Penelitian ini memiliki tujuan untuk menguji pengaruh nilai tukar terhadap return saham melalui profitabilitas. Penelitian dilakukan pada perusahaan pertambangan yang terdaftar di BEI yang berjumlah 49 perusahaan. Sampel ditentukan dengan metode purposive sampling berjumlah 7 perusahaan yang diteliti selama 3 tahun pengamatan menggunakan laporan triwulanan, sehingga terdapat 84 data amatan. Metode pengumpulan data dan teknik analisis data yang digunakan adalah metode observasi non partisipan dan analisis jalur. Hasil penelitian menunjukkan bahwa nilai tukar berpengaruh negatif signifikan pada return saham dan profitabilitas. Profitabilitas berpengaruh positif dan signifikan pada return saham, dan nilai tukar berpengaruh secara tidak langsung pada return saham melalui profitabilitas.
\end{abstract}

Kata Kunci: Return saham; Nilai Tukar; Profitabilitas.

\section{Effect of Exchange Rates on Stock Returns with Profitability as Intervening Variables}

\section{ABSTRACT}

The research aims to examine the effect of exchange rates on stock returns through profitability. The study was conducted on mining companies listed on the Stock Exchange which numbered 49 companies. Samples were determined by a purposive sampling method totaling 7 companies thatwere studied for 3 years of observation using quarterly reports, so there are 84 observation datas. Data collection methods and data analysis techniques used are non-participant observation methods and path analysis. The results showed that the exchange rate had a significant negative effect on stock returns and profitability. Profitability has a significant positive effect on stock returns, and exchange rates have indirect influence on stock returns through profitability.

Keywords: Stock Returns; Exchange Rates; Profitability.

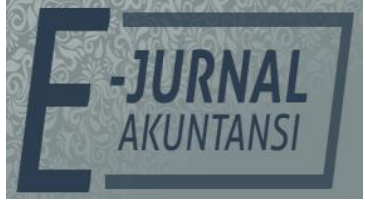

E-JA

e-Jurnal Akuntansi e-ISSN 2302-8556

Vol. 30 No. 5

Denpasar, Mei 2020

Hal.1283-1296

Artikel Masuk: 16 November 2019

Tanggal Diterima: 31 Januari 2020 


\section{PENDAHULUAN}

Pasar modal berperan penting bagi emiten yang membutuhkan tambahan dana untuk menjalankan operasional perusahaan, dan bagi investor yang memiliki kelebihan dana untuk di investasikan. Bila pasar modal efisien maka pasar modal akan memberikan return seperti yang diharapkan oleh para investor. Investor selalu menginginkan return yang tinggi namun selalu menghindari risiko. Akan tetapi, teori menyebutkan bahwa investasi yang mempunyai return tinggi pasti akan mempunyai risiko yang tinggi juga (Tandelilin, 2010).

Dalam menentukan berinvestasi, investor harus mampu menganalisis saham. Melihat saham mana yang menawarkan return dan risiko yang sesuai dengan yang investor inginkan. Investor bisa menilai saham dengan melihat kinerja perusahaannya. Kinerja yang semakin bagus, maka perusahaan itu akan memberikan return yang semakin besar. Return merupakan tujuan utama investor untuk mendapatkan hasil dari investasi yang dilakukan oleh investor. Dengan adanya return saham yang cukup tinggi akan lebih menarik para investor untuk membeli saham tersebut. Return saham mencerminkan bagaimana kinerja sebuah perusahaan sehingga investor yang akan berinvestasi bisa menjadikan return saham sebagai salah satu pertimbangan investasi yang akan investor lakukan. Harapan terhadap return ini merupakan kompensasi atas waktu dan risiko yang berhubungan dengan investasi tersebut (Tandelilin, 2010).

Kinerja perusahaan dipengaruhi oleh faktor yang berasal dari dalam maupun yang berasal dari luar perusahaan. Faktor yang berasal dari dalam atau yang disebut juga dengan faktor internal memiliki kemungkinan untuk dikembalikan oleh pihak manajemen perusahaan guna sesuai dengan yang diharapkan. Namun tidak demikian dengan faktor yang berasal dari luar perusahaan atau yang biasa disebut dengan faktor eksternal, akan sulit bahkan tidak mungkin bagi manajemen perusahaan untuk mengendalikan keadaan di luar perusahaan. Kondisi ekonomi makro dapat mempengaruhi operasi perusahaan sehari-hari. Hasil keputusan investor dalam menentukan investasi yang menguntungkan salah satunya dipengaruhi oleh kemampuan investor tersebut dalam memahami dan meramalkan kondisi ekonomi makro di masa datang. Dalam ekonomi makro terdapat beberapa indikator yang harus dipertimbangkan investor dalam membuat keputusan investasinya (Tandelilin, 2010). Tandelilin (2010), mengatakan bahwa variabel ekonomi makro yang perlu diperhatikan investor salah satunya adalah tingkat nilai kurs.

Nilai kurs adalah suatu nilai tukar mata uang asing terhadap mata uang lain (Hidayat et al., 2017). Menurut Singh et al. (2011) nilai tukar merupakan biaya untuk menukar mata uang satu negara dengan mata uang lain. Perubahan nilai tukar mempengaruhi kinerja perusahaan secara global yang kemudian kondisi ini akan mempengaruhi harga saham yang kemudian akan berpengaruh terhadap return saham (Khan et al., 2017). Pengaruh dari fluktuasi nilai rupiah terhadap nilai mata uang asing yang stabil akan memberikan sinyal positif dan mempengaruhi iklim investasi di dalam negeri. Nilai tukar yang stabil diperlukan untuk tercapainya iklim usaha yang kondusif bagi peningkatan dunia usaha (Saputra \& Dharmadiaksa, 2016). Nilai kurs yang tidak stabil akan dapat mengurangi tingkat kepercayaan investor asing terhadap perekonomian Indonesia. Ini tentu akan menimbulkan dampak negatif terhadap perdagangan 
saham di pasar modal, bagi investor asing akan cenderung melakukan penarikan modal sehingga terjadi Capital of Flow dan hal ini akan berimbas pada menurunnya tingkat return yang akan dibagikan (Suriyani and Sudiartha, 2018).

Penelitian yang telah dilakukan oleh Afiyati (2018) menemukan bahwa perubahan nilai tukar memberikan pengaruh yang positif dan signifikan terhadap return saham. Berpengaruh positif artinya depresiasi nilai tukar akan menurunkan return saham sedangkan apresiasi nilai tukar akan meningkatkan return saham. Hal ini sejalan dengan penelitian yang dilakukan oleh Suyati (2015) dan Andes \& Puspitaningtyas (2017).

Tabel 1. Kurs Transaksi Bank Indonesia Tahun 2016 s/d 2018 (Rp/1 USD)

\begin{tabular}{ccccc}
\hline No. & Tahun & Nilai $(\$)$ & Kurs Jual $(\mathrm{Rp})$ & Kurs Beli $(\mathrm{Rp})$ \\
\hline 1 & 2016 & 1 & $13,373.89$ & $13,240.86$ \\
2 & 2017 & 1 & $13,451.22$ & $13,317.04$ \\
3 & 2018 & 1 & $14,317.69$ & $14,175.17$ \\
\hline
\end{tabular}

Sumber: Data Penelitian, 2019

Kurs jual dan kurs beli dari mata uang rupiah terhadap Dolar AS dari tahun 2016 sampai dengan tahun 2018 terus mengalami depresiasi/melemah. Melemahnya kurs mata uang domestik terhadap mata uang asing dapat meningkatkan volume ekspor. Hal ini dapat meningkatkan profitabilitas perusahaan yang kemudian meningkatkan harga saham perusahaan apabila permintaan pada pasar international cukup elastis dan mempengaruhi return yang akan di terima oleh investor.

Melemahnya nilai kurs di Indonesia memberikan pengaruh besar terhadap beberapa sektor perekonomian, salah satunya adalah pada sektor pertambangan. Perusahaan pertambangan yang aktif melakukan ekspor akan mendapatkan keuntungan ketika mata uang lokal melemah, sehingga dapat meningkatkan pendapatan perusahaan dalam bentuk mata uang lokal. Sebaliknya, ketika mata uang lokal terapresiasi maka perusahaan akan mengalami kerugian karena pendapatannya berkurang ketika dikonversikan ke dalam mata uang lokal (Ariani and Merta Sudiartha, 2017).

Rasio profitabilitas merupakan rasio yang menggambarkan kemampuan perusahaan dalam mendapatkan laba melalui semua kemampuan dan sumber yang ada seperti kegiatan penjualan, kas, modal, jumlah karyawan, jumlah cabang, dan sebagainya (Adiyadnya, 2016). Peneliti kemudian menambahkan rasio profitabilitas sebagai variabel intervening untuk memediasi pengaruh nilai tukar rupiah terhadap return saham perusahaan, karena rasio ini menjadi fokus utama investor dalam memustuskan tempat untuk menginvestasikan dananya. rasio profitabilitas yang digunakan dalam penelitian ini diproksikan dengan Return on Assets (ROA).

Sinyal atau pesan merupakan suatu informasi atau pengumuman yang diterima oleh pasar, yang mengakibatkan perubahan keyakinan penerima dan memicu suatu tindakan tertentu. Pada waktu informasi diumumkan dan semua pelaku pasar sudah menerima informasi tersebut, pelaku pasar terlebih dahulu menginterpretasikan dan menganalisis informasi tersebut sebagai sinyal baik (good news) atau sinyal buruk (bad news). Jika pengumuman atau informasi yang diterima sebagai sinyal baik bagi investor, maka investor akan bereaksi dengan melakukan tindakan tertentu. 
Return saham merupakan tujuan yang ingin dicapai oleh investor. Setiap kegiatan investasi baik dalam periode waktu singkat atau panjang tetap mengharapkan diperolehnya pengembalian atas modal yang telah diberikan, baik keuntungan tersebut didapat secara langsung maupun secara tidak langsung. Semakin besar return saham yang dihasilkan oleh suatu investasi, maka akan semakin besar pula daya tarik investasi saham tersebut bagi investor, walaupun tetap memperhitungkan faktor risiko yang melekat pada investasi tersebut.

Nilai tukar memainkan peran penting dalam tingkat perdagangan suatu negara, yang sangat penting bagi sebagian besar ekonomi pasar bebas di dunia. Karena alasan ini, nilai tukar adalah yang paling banyak dilihat, dianalisis, dan dimanipulasi oleh langkah-langkah ekonomi pemerintah. Fluktuasi kurs yang tidak stabil akan dapat mengurangi tingkat kepercayaan investor asing terhadap perekonomian Indonesia. Yang selanjutnya akan menimbulkan dampak negatif terhadap perdagangan saham di pasar modal.

Return on Assets (ROA) merupakan rasio yang digunakan untuk mengukur kemampuan manajemen perusahaan dalam memperoleh laba. Menurut Kasmir (2010), ROA merupakan rasio yang menunjukkan hasil (return) atas jumlah aktiva yang digunakan dalam perusahaan. ROA juga merupakan suatu ukuran tentang efektivitas manajemen dalam mengelola investasinya. Hasil pengembalian investasi menunjukkan produktivitas dari seluruh dana perusahaan, baik modal pinjaman maupun modal sendiri. Semakin rendah rasio ROA, semakin kurang baik, demikian pula sebaliknya.

Pengaruh nilai tukar ini terhadap harga dan return saham dalam penelitian Amrillah (2016) dapat dijelaskan yaitu, bagi suatu perusahaan atau industri domestik yang kegiatan usahanya lebih banyak ekspor dan menggunakan kandungan impor yang relatip rendah, maka depresiasi mata uang domestik terhadap Dolar AS dapat meningkatkan laba perusahaan tersebut. Kenaikan laba karena selisih kurs ini dapat meningkatkan harga saham perusahaan, begitu pula sebaliknya. Hal ini kemudian didukung oleh penelitian Abdallah (2018) yang menyebutkan bahwa melemahnya nilai tukar rupiah terhadap Dolar AS akan memberikan dampak yang positif terhadap pendapatan yang akan diterima oleh perusahaan karena jumlah rupiah yang diterima oleh perusahaan akan semakin banyak apabila rupiah melemah terhadap Dolar AS. Dengan demikian dapat dikatakan bahwa nilai tukar rupiah terhadap Dolar AS berpengaruh negatif terhadap return saham perusahaan jika kegiatan dominasi perusahaan lebih banyak ekspor daripada impor.

Berdasarkan uraian diatas, maka hipotesis yang diajukan dalam penelitian ini adalah sebagai berikut.

$\mathrm{H}_{1}$ : Nilai tukar berpengaruh negatif terhadap return saham.

Melemahnya nilai tukar rupiah terhadap Dolar AS akan memberikan dampak yang positif terhadap pendapatan yang akan diterima oleh perusahaan. Hal ini disebabkan karena jumlah rupiah yang diterima oleh perusahaan akan semakin meningkat akibat ekspor. Hal ini sejalan dengan penelitian yang dilakukan Penelitian yang dilakukan oleh Pujawati (2015) dan (Adiyadnya, 2016) yang menunjukkan bahwa nilai tukar mata uang asing berpengaruh negatif terhadap ROA. Setiap penurunan nilai tukar akan mengakibatkan 
kenaikan ROA, dan sebaliknya setiap terjadinya apresiasi nilai tukar akan menyebabkan penurunan pada ROA.

Berdasarkan uraian diatas, maka hipotesis yang diajukan dalam penelitian ini adalah sebagai berikut.

$\mathrm{H}_{2}$ : Nilai tukar berpengaruh negatif terhadap profitabilitas.

Kinerja keuangan perusahaan dalam menghasilkan laba bersih dari aktiva yang digunakan akan berdampak pada pemegang saham perusahaan. ROA yang semakin bertambah menggambarkan kinerja perusahaan yang semakin baik dan keuntungan dari dividen yang diterima para pemegang saham akan semakin meningkat, atau semakin meningkatnya harga maupun return saham. Dengan kata lain, semakin besar ROA, semakin efisien rotasi aset perusahaan dan marjin laba yang diperoleh oleh perusahaan sehingga tingkat pengembalian (return) yang diterima juga meningkat (Nurhakim., 2016).

Berdasarkan uraian diatas, maka hipotesis yang diajukan dalam penelitian ini adalah sebagai berikut:

$\mathrm{H}_{3}$ : Profitabilitas berpengaruh positif terhadap return saham.

Pendapatan perusahaan meningkat ketika pendapatan ekspor dikonversikan ke dalam mata uang rupiah. Peningkatan pendapatan tersebut akan berpengaruh pula pada peningkatan laba perusahaan. Semakin baik kinerja keuangan perusahaan dalam menghasilkan laba bersih dari aktiva yang digunakan akan berdampak pada pemegang saham. Hal ini akan menjadi sinyal positif (good news) bagi investor sehingga dapat mempengaruhi keputusan investor dalam berinvestasi. Semakin banyak investor yang memutuskan untuk berinvestasi pada perusahaan, akan menyebabkan harga saham semakin meningkat sehingga return yang diperoleh juga semakin bertambah.

Berdasarkan uraian diatas, maka hipotesis yang diajukan dalam penelitian ini adalah sebagai berikut:

$\mathrm{H}_{4}$ : Nilai tukar berpengaruh secara tidak langsung terhadap return saham melalui profitabilitas.

\section{METODE PENELITIAN}

Desain penelitian menggambarkan pengaruh nilai tukar terhadap return saham melalui adanya profitabilitas yang diproksikan dengan Return on Assets (ROA). Penelitian ini dilakukan pada perusahaan pertambangan yang terdaftar di Bursa Efek Indonesia (BEI) yang dapat diakses melalui situs Bursa Efek Indonesia (BEI) yaitu www.idx.co.id. Objek dari penelitian ini adalah return saham yang dipengaruhi oleh nilai tukar dengan profitabilitas yang digunakan sebagai variabel intervening. Rumus yang digunakan dalam menghitung return saham dalam Jogiyanto (2014) adalah sebagai berikut.

$\mathrm{Ri}, \mathrm{t}=\frac{\mathrm{Pi}_{\mathrm{i}, \mathrm{t}}-\mathrm{pi}_{\mathrm{i}} \mathrm{t}-\mathrm{t}}{\mathrm{P}_{\mathrm{i}, \mathrm{t}}-1}$

Keterangan:

$\mathrm{Ri}, \mathrm{t}=$ Return Saham i pada waktu $\mathrm{t}$

$\mathrm{Pi}, \mathrm{t}=$ Harga Saham $\mathrm{i}$ pada periode $\mathrm{t}$

Pit-1 = Harga Saham pada i periode $\mathrm{t}-1$

Nilai Kurs yang dimaksud dalam penelitian ini adalah nilai tukar rupiah terhadap Dolar AS yang diperoleh dari situs www.bi.go.id selama tahun 
pengamatan 2016-2018. Nilai tukar yang digunakan adalah nilai tukar rupiah pada saat laporan keuangan triwulan tiap perusahaan diterbitkan. Return on Assets dalam penelitian ini dapat dirumuskan sebagai berikut.

Return on Assets $=\frac{\text { Laba Bersih }}{\text { Total Aset }}$

Populasi dalam penelitian ini adalah seluruh perusahaan pertambangan yang berjumlah 49 perusahaan yang terdaftar di Bursa Efek Indonesia. Sampel yang dipilih dalam penelitian ini menggunakan metode non probability sampling dengan teknik purposive sampling. Adapun kriteria yang dijadikan dasar pemilihan anggota sampel dalam penelitian ini diantaranya, perusahaan pertambangan yang telah terdaftar di Bursa Efek Indonesia selama periode penelitian yaitu tahun 2016-2018, perusahaan pertambangan yang menggunakan laporan keuangan dalam bentuk rupiah, perusahaan pertambangan yang memiliki laporan keuangan yang lengkap selama periode penelitian yaitu tahun 2016-2018.

Data dikumpulkan dengan menggunakan metode observasi non partisipan. Data dianalisis menggunakan analisis jalur seperti yang digambarkan sebagai berikut.

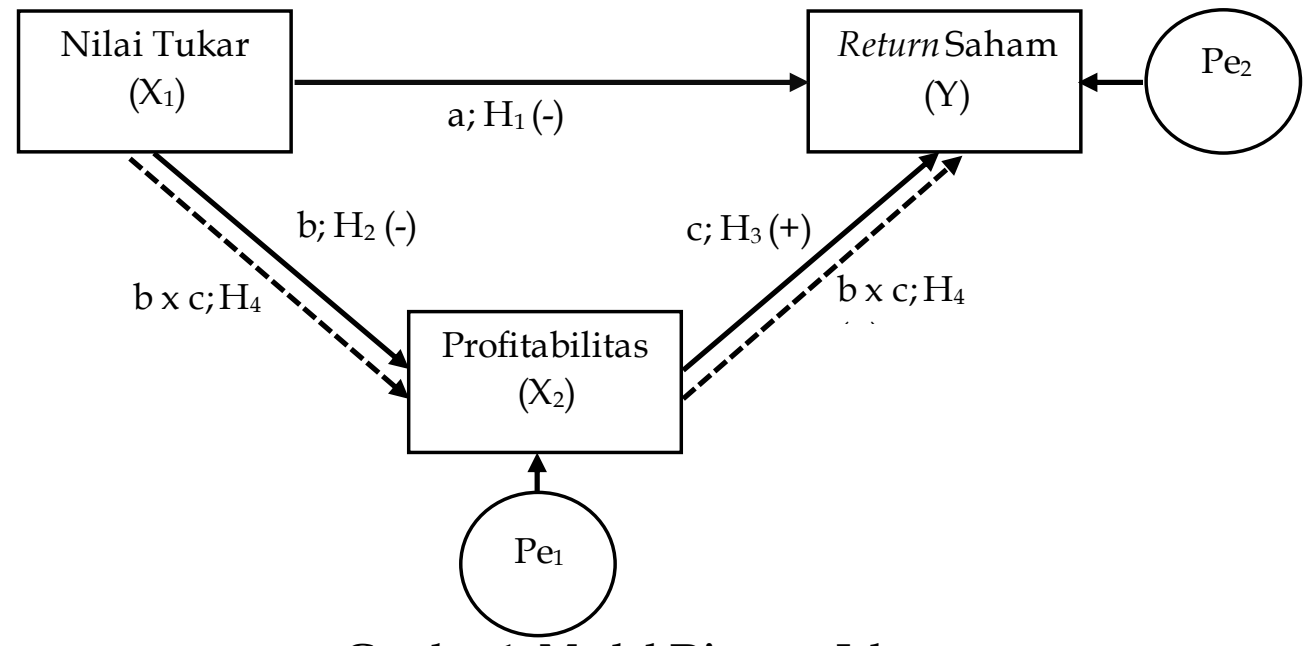

Sumber: Data Penelitian, 2019

Gambar 1. Model Diagram Jalur

Keterangan:

$\begin{array}{ll}\mathrm{X}_{1} & =\text { Nilai Tukar } \\ \mathrm{X}_{2} & =\text { Profitabilitas } \\ \mathrm{Y} & =\text { Return Saham } \\ \mathrm{a}, \mathrm{b}, \mathrm{c} & =\text { Standardisasi Koefisien Regresi } \\ \mathrm{Pe}_{1}, \mathrm{Pe}_{2} & =\text { error }\end{array}$

\section{HASIL DAN PEMBAHASAN}

Bursa Efek Indonesia (BEI) merupakan pasar modal yang ada di Indonesia dan memiliki peran penting dalam perekonomian Indonesia yaitu berupa fungsi ekonomi dan fungsi keuangan. BEI dalam melakukan publikasi informasi terkait dengan perkembangan bursa biasanya melalui media cetak dan elektronik untuk kemudahan akses informasi. Perusahaan yang terdaftar dan aktif menawarkan 
saham atau obligasi di BEI diklasifikasikan menjadi sembilan sektor yaitu sektor pertanian, sektor pertambangan, sektor industri dasar dan kimia, sektor aneka indutri, sektor industri barang konsumsi, sektor properti dan realestate, sektor infrastruktur, ulititas dan transportasi, sektor keuangan, sektor perdagangan, jasa dan investasi. Populasi yang digunakan dalam penelitian ini adalah seluruh perusahaan pertambangan yang terdaftar di BEI pada tahun 2016 sampai dengan 2018 yaitu sebanyak 49 perusahaan. Perusahaan yang menjadi sampel penelitian ditentukan melalui proses penyeleksian dengan beberapa kriteria yang telah ditetapkan seperti yang disajikan dalam Tabel 2.

Tabel 2. Ringkasan Perolehan Sampel Penelitian

\begin{tabular}{|c|c|c|}
\hline No. & Kriteria & Jumlah \\
\hline 1 & $\begin{array}{l}\text { Perusahaan Pertambangan yang telah terdaftar di Bursa Efek } \\
\text { Indonesia selama periode penelitian yaitu tahun 2016-2018 }\end{array}$ & 49 \\
\hline 2 & $\begin{array}{l}\text { Perusahaan Pertambangan yang tidak menggunakan laporan } \\
\text { keuangan dalam bentuk rupiah pada periode penelirian 2016- } \\
2018\end{array}$ & (34) \\
\hline 3 & $\begin{array}{l}\text { Perusahaan pertambangan yang menggunakan laporan } \\
\text { keuangan dalam bentuk rupiah dan tidak menerbitkanlaporan } \\
\text { keuangan lengkap pada periode penelitian 2016-2018 }\end{array}$ & (8) \\
\hline 4 & Jumlah perusahaan yang terpilih sebagai sampel & 7 \\
\hline 5 & Total data amatan dalam tiga tahun penelitian & 84 \\
\hline
\end{tabular}

Sumber: Data Penelitian, 2019

Berdasarkan Tabel 2. jumlah sampel yang diperoleh dalam penelitian ini sebanyak 7 sampel dan jumlah data amatan dengan pengamatan selama 3 tahun dengan menggunakan laporan keuangan triwulan sehingga menghasilkan 84 data amatan.

Tabel 3. Daftar Perusahaam Pertambangan yang Terpilih sebagai Sampel Penelitian

\begin{tabular}{|c|c|c|}
\hline No. & Kode & Nama Perusahaan \\
\hline 1 & ANTM & Aneka Tambang Tbk. \\
\hline 2 & CTTH & Citatah Tbk. \\
\hline 3 & DKFT & Central Omega Resources Tbk. \\
\hline 4 & ELSA & Elnusa Tbk. \\
\hline 5 & PTBA & Bukit Asam Tbk. \\
\hline 6 & SMMT & Golden Eagle Energy Tbk. \\
\hline 7 & TINS & Timah Tbk. \\
\hline
\end{tabular}

Sumber: Data Penelitian, 2019

Tabel 3. merupakan nama perusahaan pertambangan yang terdaftar di Bursa Efek Indonesia (BEI) yang terpilih menjadi sampel penelitian setelah menggunakan teknik purposive sampling.

Uji normalitas merupakan salah satu uji asumsi klasik yang harus dipenuhi sebelum model regresi dapat dikatakan layak untuk digunakan. Model regresi yang layak adalah yang memiliki nilai Asymp.sig (2-tailed) $>$ a. $(0,05)$ ketika dilakukan uji normalitas seperti yang ditunjukkan oleh Tabel 4. bertujuan untuk mengetahui normal atau tidaknya distribusi variabel residual. 
Tabel 4. Hasil Uji Normalitas Regresi Substruktur 1 dan 2

\begin{tabular}{lcc}
\hline & $\begin{array}{c}\text { Unstandardized Residual } \\
\text { Struktur 1 }\end{array}$ & $\begin{array}{c}\text { Unstandardized } \\
\text { Residual Struktur 2 }\end{array}$ \\
\hline $\mathrm{N}$ & 84 & 84 \\
Kolmogorov-Smirnov Z & 1,604 & 0,827 \\
Asymp.Sig.(2-tailed) & 0,072 & 0,500 \\
\hline
\end{tabular}

Sumber: Data penelitian, 2019

Berdasarkan data pada Tabel 4, nilai signifikansi model regresi baik substruktur 1 maupun substruktur 2 berada di atas 0,05 sehingga disimpulkan bahwa model berdistribusi normal dan layak untuk dilanjutkan dalam penelitian.

Uji autokorelasi bertujuan untuk menguji apakah dalam model regresi linier ada korelasi antara kesalahan pengganggu pada periode $t$ dengan kesalahan pengganggu pada periode $\mathrm{t}-1$ (sebelumnya). Jika suatu model regresi mengandung gejala aukorelasi, maka prediksi yang dilakukan dengan model tersebut akan tidak baik atau dapat memberikan hasil prediksi yang menyimpang. Uji autokorelasi dalam penelitian ini menggunakan uji DurbinWatson (DW test) atau d statistik.

a. Nilai $\mathrm{dU}<\mathrm{dW}<(4-\mathrm{dU})$, maka tidak terjadi autokorelasi

b. Nilai $\mathrm{dU}<\mathrm{dL}$, maka terjadi autokorelasi positif

c. Nilai $\mathrm{dW}>(4-\mathrm{dL})$, maka terjadi autokorelasi negatif

d. Nilai $\mathrm{dL}<\mathrm{dW}<\mathrm{dU}$ atau $(4-\mathrm{dU})<\mathrm{dW}<(4-\mathrm{dL})$, maka tidak dapat ditarik kesimpulan mengenai ada tidaknya autokorelasi.

Hasil uji autokorelasi dalam penelitian disajikan dalam Tabel 5.

Tabel 5. Hasil Uji Autokorelasi Regresi Substruktur 1 dan 2

\begin{tabular}{cccccc}
\hline Struktur & $\mathrm{dl}$ & $\mathrm{Du}$ & $4-\mathrm{du}$ & $\mathrm{DW}$ & Simpulan \\
\hline 1 & 1,6212 & 1,6693 & 2,3307 & 1,714 & Bebas autokorelasi \\
2 & 1,5969 & 1,6942 & 2,3058 & 1,857 & Bebas autokorelasi \\
\hline
\end{tabular}

Sumber: Data Penelitian, 2019

Tabel 5. menunjukkan bahwa besarnya nilai Durbin Watson untuk struktur 1 sebesar 1,714 Nilai D-W menurut tabel dengan $\mathrm{n}=84$ dan $\mathrm{k}=1$ didapat nilai $\mathrm{dl}=1,6212$ dan nilai $\mathrm{du}=1,693$. Oleh karena nilai $\mathrm{du}<\mathrm{dw}<(4-\mathrm{du})$ yaitu $(1,66693<1,714<2,3307)$, maka dapat disimpulkan tidak terdapat autokorelasi antar residual. Durbin Watson untuk struktur 2 menunjukkan nilai sebesar 1,857 . Nilai $\mathrm{D}-\mathrm{W}$ menurut tabel dengan $\mathrm{n}=84$ dan $\mathrm{k}=2$ didapat nilai $\mathrm{dl}=1,5969$ dan nilai du=1,694. Oleh karena nilai $\mathrm{du}<\mathrm{dw}<(4-\mathrm{du})$ yaitu $(1,6942<$ $1,857<2,3058)$, maka dapat disimpulkan tidak terdapat autokorelasi antar residual.

Model regresi yang bebas dari heteroskedastisitas adalah model yang memiliki nilai Uji Glejser diatas $\alpha=0,05$. Uji heteroskedastisitas dalam penelitian ini disajikan dalam Tabel 6 dan 7, sebagai berikut.

Tabel 6. Hasil Uji Heteroskedastisitas Regresi Substruktur 1

\begin{tabular}{ccc}
\hline & Model & Signifkansi \\
\hline 1 & (Constant) & 0,000 \\
& Nilai tukar & 0,309 \\
\hline
\end{tabular}

Sumber: Data Penelitian, 2019 
Berdasarkan Tabel 6. dapat dilihat bahwa nilai signifikansi dari variabel nilai tukar sebesar 0,309. Nilai tersebut lebih besar dari 0,05 yang berarti tidak terdapat pengaruh antara variabel bebas terhadap absolute residual. Dengan demikian, model yang dibuat tidak mengandung gejala heteroskedastisitas.

Tabel 7. Hasil Uji Heteroskedastisitas Regresi Substruktur 2

\begin{tabular}{llc}
\hline & Model & Signifikansi \\
\hline 1 (Constant) & 0,000 \\
Nilai Tukar & 0,987 \\
ROA & 0,078 \\
\hline
\end{tabular}

Sumber: Data Penelitian, 2019

Pada Tabel 7. dapat dilihat bahwa nilai signifikansi dari variabel nilai tukar sebesar 0,987 dan nilai signifikansi dari variabel profitabilitas sebesar 0,078. Nilai tersebut lebih besar dari 0,05 yang berarti tidak terdapat pengaruh antara variabel bebas terhadap absolute residual. Dengan demikian, model yang dibuat tidak mengandung gejala heteroskedastisitas.

Model yang telah lulus uji asumsi klasik selanjutnya akan dilakukan uji analisis jalur guna menentukan pengaruh antar variabel bebas terhadap variabel terikat.

Tabel 8. Hasil Analisis Jalur Regresi Substruktur 1

\begin{tabular}{lccc}
\hline \multicolumn{1}{c}{ Variabel } & $\begin{array}{c}\text { Standardized Coefficients } \\
(\mathrm{B})\end{array}$ & thitung & Sig. uji t \\
\hline Nilai tukar $\left(\mathrm{X}_{1}\right)$ & $-0,596$ & $-6,717$ & 0,000 \\
R Square & 0,355 & & \\
Adjusted RSquare & 0,347 & & \\
\hline
\end{tabular}

Sumber: Data Penelitian, 2019

Berdasarkan hasil analisis jalur substruktur 1 seperti yang disajikan pada Tabel 8, maka dapat dibuat persamaan struktural sebagai berikut:

$$
\begin{array}{ll}
\mathrm{X}_{2} & =\mathrm{bX} \mathrm{X}_{1}+\mathrm{e}_{1} \\
\mathrm{X}_{2} & =-0,596 \mathrm{X}_{1}+\mathrm{e}_{1}
\end{array}
$$

Nilai beta variabel nilai tukar bernilai negatif $-0,596$ dengan nilai signifikansi uji t 0,000 kurang dari 0,05. Hal ini menunjukkan bahwa variabel nilai tukar memiliki pengaruh negatif yang signifikan terhadap variabel profitabilitas. Besarnya pengaruh variabel bebas terhadap variabel terikat yang ditunjukkan oleh nilai determinasi total (Adjusted $R$ Square) sebesar 0,347 mempunyai arti bahwa sebesar $34,7 \%$ variasi profitabilitas dipengaruhi oleh variasi nilai tukar, sedangkan sisanya sebesar $65,3 \%$ dijelaskan oleh faktor lain yang tidak dimasukkan ke dalam model.

Tabel 9. Hasil Analisis Jalur Regresi Substruktur 2

\begin{tabular}{lccc}
\hline \multicolumn{1}{c}{ Variabel } & $\begin{array}{c}\text { Standardized Coefficients } \\
(\mathrm{B})\end{array}$ & thitung & Sig. uji t \\
\hline Nilaitukar $\left(\mathrm{X}_{1}\right)$ & $-0,261$ & $-2,223$ & 0,029 \\
Profitabilitas $\left(\mathrm{X}_{2}\right)$ & 0,332 & 2,826 & 0,006 \\
RSquare & 0,281 & & \\
Adjusted R Square & 0,263 & & \\
Sumber: Data Penelitian, 2019 & & &
\end{tabular}


Berdasarkan hasil analisis jalur substruktur 2 seperti yang disajikan pada Tabel 9., maka dapat dibuat persamaan struktural sebagai berikut:

$$
\begin{array}{ll}
\mathrm{Y} & =\mathrm{a} \mathrm{X}_{1}+\mathrm{c} \mathrm{X}_{2}+\mathrm{e}_{2} \\
\mathrm{Y} & =-0,261 \mathrm{X}_{1}+0,332 \mathrm{X}_{2}+\mathrm{e}_{2}
\end{array}
$$

Nilai beta variabel nilai tukar bernilai negatif $-0,261$ dan nilai beta variabel profitabilitas bernilai positif 0,332 . Hal ini menunjukkan bahwa nilai tukar berpengaruh negatif terhadap return saham sedangkan profitabilitas memiliki pengaruh positif terhadap return saham. Nilai signifikansi nilai tukar 0,029 dan nilai signifikansi profitabilitas 0,006 keduanya kurang dari 0,050. Hal ini menunjukkan bahwa variabel nilai tukar dan profitabilitas memiliki pengaruh yang signifikan terhadap return saham. Besarnya pengaruh variabel bebas terhadap variabel terikat y ang ditunjukkan oleh nilai determinasi total (Adjusted $R$ Square) sebesar 0,263 mempunyai arti bahwa sebesar $26,3 \%$ variasi return saham dipengaruhi oleh variasi nilai tukar dan profitabilitas, sedangkan sisanya sebesar $73,7 \%$ dijelaskan oleh faktor lain yang tidak dimasukkan ke dalam model.

Berdasarkan model substruktur 1 dan substruktur 2, maka dapat disusun model diagram jalur akhir. Sebelum menyusun model diagram jalur akhir, terlebih dahulu dihitung nilai standar eror sebagai berikut :

$\mathrm{Pe}_{\mathrm{i}}=\sqrt{1-\mathrm{R}_{\mathrm{i}}{ }^{2}}$
$\mathrm{Pe}_{1}=\sqrt{1-R_{1}{ }^{2}}=\sqrt{1-0,347}=0,808$
$\mathrm{Pe}_{2}=\sqrt{1-R_{2}{ }^{2}}=\sqrt{1-0,263}=0,858$

Berdasarkan perhitungan pengaruh error (Pei), didapatkan hasil pengaruh error $\left(\mathrm{Pe}_{1}\right)$ sebesar 0,808 dan pengaruh error $\left(\mathrm{Pe}_{2}\right)$ sebesar 0,858 . Hasil koefisien determinasi total adalah sebagai berikut :

$$
\begin{aligned}
\mathrm{R}_{\mathrm{m}}^{2} & =1-\left(\mathrm{Pe}_{1}\right)^{2}\left(\mathrm{Pe}_{2}\right)^{2} \\
& =1-(0,808)^{2}(0,858)^{2} \\
& =1-(0,653)(0,736) \\
& =1-0,4806=0,5194
\end{aligned}
$$

Nilai determinasi total sebesar 0,5194 mempunyai arti bahwa sebesar 51,94\% variasi return saham pada Perusahaan Pertambangan dipengaruhi oleh variasi nilai tukar dan profitabilitas, sedangkan sisanya sebesar 48,06\% djelaskan oleh faktor lain yang tidak dimasukkan ke dalam model.

Berdasarkan hasil analisis jalur yang terdapat pada Tabel 9. menujukkan bahwa nilai nilai beta nilai tukar negatif sebesar -0,261 dengan tingkat signifikansi sebesar 0,029 lebih kecil dari 0,050. Hasil ini mengindikasikan bahwa $\mathrm{H}_{1}$ diterima, sehingga dapat disimpulkan bahwa nilai tukar rupiah terhadap Dolar AS berpengaruh negatif dan signifikan terhadap return saham. Hal ini menunjukkan bahwa depresiasi nilai tukar rupiah terhadap Dolar AS akan menyebabkan return saham semakin meningkat. depresiasi nilai tukar rupiah terhadap Dolar AS juga dapat menguntungkan perusahaan yang kegiatan usahanya lebih berfokus pada kegiatan ekspor dan menggunakan laporan keuangan dalam bentuk rupiah. Hasil ini sejalan dengan penelitian yang dilakukan oleh Indriastuti (2017) menyatakan bahwa nilai kurs berpengaruh negatif dan signifikan terhadap return saham. Beberapa peneliti yang 
menemukan pengaruh negatif ini diantaranya penelitian dari Pujawati (2015), Saputra and Dharmadiaksa (2016), Sudarsono and Sudiyatno (2016), Suriyani and Sudiartha (2018), Sharma (2015) dan Artaya (2014).

Berdasarkan hasil analisis jalur yang terdapat pada Tabel 8. menujukkan bahwa nilai beta nilai tukar negatif sebesar -0,596 dengan nilai signifikansi sebesar 0,000 < 0,050 yang mengindikasikan $\mathrm{H}_{2}$ diterima, sehingga dapat disimpulkan bahwa nilai tukar berpengaruh negatif dan signifikan terhadap profitabuilitas. Hal ini menunjukkan bahwa depresiasi nilai tukar rupiah terhadap Dolar AS akan menyebabkan profitabilitas semakin tinggi. Terjadinya depresiasi nilai tukar rupiah terhadap Dolar AS akan memberikan dampak yang positif terhadap pendapatan yang akan diterima oleh perusahaan. Hal ini disebabkan karena jumlah rupiah yang diterima oleh perusahaan akan semakin meningkat akibat ekspor. Hal ini sejalan dengan penelitian yang dilakukan Penelitian yang dilakukan oleh Pujawati (2015), Artaya (2014), dan (Adiyadnya, 2016) yang menunjukkan bahwa nilai tukar mata uang asing berpengaruh negatif terhadap ROA.

Berdasarkan hasil analisis jalur yang terdapat pada Tabel 9. menujukkan bahwa nilai beta profitabilitas positif sebesar 0,332 dengan nilai signifikansi sebesar $0,006<0,050$, yang mengindikasikan $\mathrm{H}_{3}$ diterima. Hasil ini mempunyai arti bahwa profitabilitas berpengaruh positif dan signifikan terhadap return saham yang diproksikan dengan ROA (Return on Assets). Hal ini menandakan profitabilitas suatu perusahaan akan mempengaruhi kinerja perusahaan sehingga berpengaruh pula terhadap return saham. Semakin tinggi tingkat profitabilitas perusahaan, maka semakin tinggi pula return saham yang akan diterima. Hasil ini kemudian didukung oleh penelitian yang dilakukan Nurhakim (2016), Geriadi (2017), Adyatmika \& Wiksuana (2018), Adiyadnya (2016), dan Chatarine (2016) menyebutkan bahwa profitabilitas berpengaruh positif dan signifikan terhadap return saham.

Berdasarkan hasil analisis jalur pendugaan parameter dan perhitungan koefisien path diperoleh hasil yaitu, pengaruh langsung yang diberikan nilai tukar terhadap return saham sebesar -0,261. Pengaruh tidak langsung nilai tukar terhadap return saham melalui profitabilitas adalah perkalian antara nilai beta nilai tukar terhadap profitabilitas dengan nilai beta profitabilitas terhadap return saham yaitu, 0,596 x 0,332 $=-0,198$. Berdasarkan hasil penelitian di atas, hasil pengaruh langsung diperoleh sebesar -0,261 dan pengaruh tidak langsung sebesar -0,198. Pengaruh tidak langsung mempunyai nilai yang lebih besar daripada pengaruh langsung, yang menunjukkan bahwa variabel profitabilitas mampu memediasi pengaruh variabel nilai tukar terhadap return saham. Berdasarkan pernyataan Solimun (2010) profitabilitas dikatakan sebagai variabel mediasi sebagian (parsial mediation), jika koefisien regresi (b) dan (c) signifikan serta (a) juga signifikan. Oleh karena itu maka $\mathrm{H}_{4}$ diterima atau dengan kata lain nilai tukar berpengaruh secara tidak langsung terhadap return saham melalui profitabilitas. 


\section{SIMPULAN}

Hasil penelitian membuktikan bahwa nilai tukar berpengaruh negatif dan signifikan terhadap return saham dan profitabilitas. Hasil ini menunjukkan bahwa depresiasi nilai tukar rupiah terhadap Dolar AS dapat meningkatkan return saham, dan meningkatkan tingkat profitabilitas perusahaan karena selisih kurs yang diterima akibat ekspor dapat meningkatkan laba perusahaan. Selain itu, hasil penelitian juga menunjukkan bahwa profitabilitas berpengaruh positif dan signifikan pada return saham, dan nilai tukar berpengaruh secara tidak langsung terhadap return saham melalui profitabilitas. Penelitian ini memperoleh hasil bahwa profitabilitas mampu menjadi variabel mediasi sebagian pada pengaruh nilai tukar terhadap return saham. Depresiasi nilai tukar dapat dijadikan sebagai bahan pertimbangan untuk meningkat jumlah ekspor sehingga profitabilitas dan return saham juga dapat meningkat. Penelitian ini diharapkan dapat menjadi bahan pertimbangan dalam menentukan perusahaan yang ingin dijadikan tujuan investasi ketika terjadinya depresiasi nilai tukar rupiah.

\section{REFERENSI}

Abdallah, Z. (2018). Pengaruh Nilai Tukar Rupiah Terhadap Return Saham Dengan Return On Asset Sebagai Variabel Intervening Pada Perusahaan Rokok. Jurnal Akuntansi, 14(1), 1-10. http://dx.doi.org/10.24217

Adiyadnya, S. (2016). Pengaruh Beberapa Variabel Ekonomi Makro Terhadap Profitabilitas dan Return Saham pada Industri Perbankan di BEI. E-Jurnal Ekonomi dan Bisnis Universitas Udayana, 5(8), 2579-2608, https://ojs.unud.ac.id/index.php/EEB/article/view/16233.

Adyatmika, P. and Wiksuana (2018). Pengaruh Inflasi dan Leverage terhadap Profitabilitas dan Return Saham pada Perusahaan Manufaktur di Bursa Efek Indonesia. E-Jurnal Ekonomi dan Bisnis Universitas Udayana, 3, 615648. https://ojs.unud.ac.id/index.php/EEB/article/view/36496.

Afiyati, H. T. (2018). Pengaruh Inflasi, BI Rate dan Nilai Tukar terhadap Return Saham (Studi pada Perusahaan Subsektor Food \& Beverages yang Terdaftar di Bursa Efek Indonesia Periode 2013-2016). Jurnal Administrasi Bisnis, $61(2)$,

123. http://administrasibisnis.studentjournal.ub.ac.id/index.php/jab/article /view/2583.

Amrillah, M. F. (2016). Pengaruh Nilai Tukar Rupiah (Kurs), Inflasi dan Pertumbuhan Ekonomi terhadap Return Saham pada Perusahaan Perbankan yang Terdaftar di Bursa Efek Indonesia (BEI) Periode 20082014. Jurnal Administrasi Bisnis, Manajemen dan Ekonomi, 2(2), 232-250. http://journal.uir.ac.id/index.php/valuta/article/view/1157.

Andes, S. L. and Puspitaningtyas, Z. (2017). Pengaruh Inflasi, Kurs Rupiah dan Suku Bunga terhadap Return Saham Perusahaan Manufaktur. Jurnal Akuntansi Keuangan dan Bisnis, 10(2), 8-16. https://jurnal.pcr.ac.id/index.php/jakb/article/view/1409.

Ariani, N. and Merta Sudiartha (2017). Pengaruh Leverage, Profitabilitas, Dan Likuiditas Terhadap Keputusan Hedging Perusahaan Sektor Pertambangan di Bursa Efek Indonesia. E-Jurnal Manajemen Unud, 6(1), 347-374. 
https://ojs.unud.ac.id/index.php/Manajemen/article/view/26769.

Artaya (2014). Pengaruh Faktor Ekonomi Makro, Risiko Investasi dan Kinerja Keuangan Terhadap Return Saham Perusahaan di Bursa Efek Indonesia (BEI). E-Jurnal Ekonomi dan Bisnis Universitas Udayana, 03, 2-9. Available at: https://ojs.unud.ac.id/index.php/EEB/article/view/9965.

Brigham, Eugene.F dan Joel F. Houston. (2001). Manajemen Keuangan. Edisi Kedelapan Buku 2. Jakarta: Erlangga

Chatarine, A. (2016). Pengaruh Risiko Kredit dan Risiko Nilai Tukar terhadap Profitabilitas dan Return Saham Perbankan di BEI. E-Jurnal Ekonomi Dan Bisnis Universitas Udayana, 11, 3683-3712. https://ojs.unud.ac.id/index.php/EEB/article/view/22974.

Geriadi, A. D. (2017). Pengaruh Inflasi terhadap Return Saham pada Perusahaan Properti dan Real Estate yang terdaftar di Bursa Efek Indonesia (Risiko Sistematis dan Profitabilitas sebagai Variabel Mediasi). E-Jurnal Ekonomi dan Bisnis Universitas Udayana, 6(9), 3435-3462. https://ojs.unud.ac.id/index.php/EEB/article/view/33381.

Hasibuan, M. S. P. (2006). Manajemen Perbankan. . Jakarta : Bumi Aksara.

Hartono, J. (2014). Teori Portofolio dan Analisis Investasi. Yogyakarta: BPFEYogyakarta

Hidayat, L. R. et al. (2017). Pengaruh Inflasi, Suku Bunga dan Nilai Tukar Rupiah serta Jumlah Uang Beredar terhadap Return Saham. 19(2), 148-154, http://journal.feb.unmul.ac.id/index.php/forumekonomi/article/view/ 2121.

Indriastuti, A. (2017). Pengaruh Volume Perdagangan, Kurs dan Risiko Pasar Terhadap Return Saham. Jurnal STIE Semarang, 9(1), pp. 72-80. https://media.neliti.com/media/publications/134235-ID-pengaruhvolume-perdagangan-kurs-dan-ris.pdf

Kasmir. (2010). Analisis Laporan Keuangan (Ed. Ke-3). . Jakarta: Rajawali Pers.

Khan, M., Gul, F. and Ali, E. (2017). Factors Influencing Stock Returns in Listed Firms of Karachi Stock Exchange. A Research Journal of Commerce, Economics, and Social Sciences, 11(2), 248-251. doi: 10.24312/paradigms110219.

Khan, M. K. et al. (2017). Nexuses between Economic Factors and Stock Returns in China. International Journal of Economics and Finance, 9(9), 182. doi: 10.5539/ijef.v9n9p182.

Nurhakim Anistia, Irni, Y. and Iradianty, A. (2016). The Effect of Profitability and Inflation on Stock Return At Pharmaceutical Industries At BEI in the Period of 2011-2014. Asia Pacific Journal of Advanced Business and Social Studies, 2(2), 202-210. https://apiar.org.au/wpcontent/uploads/2016/08/17_apjabss_icabss_brr750_biz-202-210.pdf.

Pujawati, E. (2015). Pengaruh Nilai Tukar terhadap Return Saham dengan Profitabilitas Sebagai Variabel Intervening. E-Jurnal Ekonomi dan Bisnis Universitas Udayana, 04, 220-242. https://ojs.unud.ac.id/index.php/EEB/article/view/10135.

Saputra, A. A. and Dharmadiaksa (2016). Pengaruh Tingkat Suku Bunga, Nilai Tukar Rupiah, Leverage dan Profitabilitas pada Return Saham. E-Jurnal Akuntansi Universitas Udayana, 16, pp. 1007-1033. Available at: 
https://ojs.unud.ac.id/index.php/Akuntansi/article/view/20600.

Scott, B., \& Brigham, E. F. (2008). Essentials of Managerial Finance. South-Western: USA.

Singh, T., Mehta, S. and Varsha, M. S. (2011). Macroeconomic Factors and Stock Returns: Evidence from Taiwan. Journal of Economics and International Finance, 2(4), 217-227, http://www.academicjournals.org/JEIF.

Solimun. (2010). Analisis Multivariat Pemodelan Struktural Metode Partial Least Square-PLS. Malang: CV Citra.

Sudarsono, B. and Sudiyatno, B. (2016). Faktor-faktor yang Mempengaruhi Return Saham pada Perusahaan Property dan Real Estate yang Terdaftar pada Bursa Efek Indonesia Tahun2009 s/d 2014. Jurnal Bisnis Dan Ekonomi, 23(1), 30-51, https://www.unisbank.ac.id/ojs/index.php/fe3/article/view/4304.

Suriyani and Sudiartha, M. (2018). Pengaruh Tingkat Suku Bunga, Inflasi dan Nilai Tukar Terhadap Return Saham di Bursa Efek Indonesia. E-Jurnal Manajemen Unud, 7(6), pp. 3172-3200. doi: https://doi.org/10.24843/EJMUNUD.2018.v7.i06.p12.

Suyati, S. (2015). Pengaruh Inflasi, Tingkat Suku Bunga dan Nilai Tukar Rupiah/US Dollar Terhadap Return Saham Properti Yang Terdaftar Di Bursa Efek Indonesia. Ilmiah UNTAG Semarang, 4(3), pp. 70-86. http://jurnal.untagsmg.ac.id/index.php/sa/article/viewFile/169/230.

Tandelilin, E. (2010). Portofolio dan Investasi Teori dan Aplikasi. Edisi pertama. Yogyakarta: Kanisius

Widyastuti, M. (2017). Analysis of Effects of Inflation, Interest Rates, Rupiah Exchange Rate toward Composite Stock Price Index with the Gross Domestic Product as Moderation Variable in the Indonesia Stock Exchange. The International Journal of Business \& Management, 5(1), pp. 3542, ISSN 2321-8916. Available at: http://repository.ukdc.ac.id/id/eprint/503 